
\title{
$\begin{array}{ll}\text { Research Square } & \begin{array}{l}\text { Preprints are preliminary reports that have not undergone peer review. } \\ \text { They should not be considered conclusive, used to inform clinical practice, } \\ \text { or referenced by the media as validated information. }\end{array}\end{array}$
}

\section{Climate Change In The Argentinean Wheat Region: Temperature And Precipitation At Two Contrasting Sites}

Silvana Marisol Luján Basile ( $\square$ marisol_basile@yahoo.com.ar)

UNICEN: Universidad Nacional del Centro de la Provincia de Buenos Aires https://orcid.org/0000-0001-7312-9743

Jorge Alberto Tognetti

Universidad Nacional de Mar del Plata. Facultad de Ciencias Agrarias. Laboratorio de Fisiología Vegetal. *Comisión de Investigaciones Científicas: Comision de Investigaciones Cientificas de la Provincia de Buenos Aires

Marcelo Luciano Gandini

Universidad Nacional del Centro de la Provincia de Buenos Aires. Facultad de Agronomía. Laboratorio de Investigación y Servicios en Teledetección William John Rogers

Universidad Nacional del Centro de la Provincia de Buenos Aires. Facultad de Agronomía. Laboratorio de Biología Funcional y Biotecnología (BIOLAB) INBIOTEC-CONICET-CIC-CIISAS*Consejo Nacional de Investigaciones Científicas y Tecnológicas (CONICET)

\section{Research Article}

Keywords: temperature change, precipitation change, mean variables, extreme variables, Argentina, wheat region

Posted Date: May 26th, 2021

DOI: https://doi.org/10.21203/rs.3.rs-435416/v1

License: (a) (1) This work is licensed under a Creative Commons Attribution 4.0 International License. Read Full License

Version of Record: A version of this preprint was published at Theoretical and Applied Climatology on January 22nd, 2022. See the published version at https://doi.org/10.1007/s00704-022-03936-6. 


\section{Abstract}

Global climate change is shifting temperature and precipitation regimes, which is modifying the environments that define wheat yield and quality. The current work characterises the changes that have occurred in the thermal and hydric environment in two contrasting sites of the wheat growing region of Argentina, allowing comparison between sites for these changes and for how the changes are accelerating. Temperature and precipitation variables were analysed by regression and trend testing (Mann Kendall), and future projections were made based upon significant relationships. The two sites compared were in the zones around the cities of Azul in the Province of Buenos Aires and Marcos Juárez in the Province of Córdoba, located approximately $500 \mathrm{~km}$ apart. The climate data analysed covered the period 1931-2014 for Azul and 1952-2014 for Marcos Juárez. At both sites, temperatures increased significantly in mean and extreme values over these periods, where the rate of change accelerated during the first years of the 21 st century. The changes observed were in general more pronounced in Marcos Juárez than in Azul. Furthermore, in Marcos Juárez, mean precipitation increased from September to December and there was a higher frequency of extremes of precipitation greater than $100 \mathrm{~mm}$ in September and October during the early 21 st century. Evidence was found for temperature rise and the occurrence of extreme temperature and precipitation events occurring differently between sites, as well as for its acceleration rate in the early 21 st century. The projected future changes made implied that wheat yield is expected to suffer losses over the coming century.

\section{Introduction}

The burgeoning global demand for food, feedstuff and biocombustible will require dramatic increases in wheat and other staple crop yields. According to Reynolds et al. (2009), increases of $50 \%$ in wheat yield are feasible, principally by improving potential yield (Hall and Richards 2013); however, in order to achieve this, it will be indispensable to reduce climate change and attenuate its effects upon crop yield (IPCC 2018, Asseng et al. 2015). This change, driven mainly by the anthropogenic emission of greenhouse gases (ONU 1998), leads to pronounced modification of the climate system, principally in temperature increase due to its effect on the balance between incoming solar radiation and outgoing infrared (thermal) radiation (IPCC 2007a). Such human influence appears to be the predominant long-term factor for global temperature rise (Medhaug et al. 2017), evident once short-term temperature changes caused by the El Niño Southern Oscillation (ENSO), volcanic aerosols and solar variation are taken into account (Foster and Rahmstorf 2011, De Saedeleer 2016).

Mean earth surface temperature has risen constantly since the twentieth century, with the decade of the 2000s being the hottest to date and where the number and period of sub-zero temperature days has reduced almost without exception in each country where the variable has been examined (Stocker et al. 2013); this, in spite of the hiatus reported by Chen and Tung (2014) though refuted by De Saedeleer (2016). Also, since 1980 increases have been observed for temperature and precipitation for the main wheat crop regions, amongst other crop regions (maize, rice and soybean) (Lobell et al. 2011).

The 2015 Paris Agreement includes the long-term global goal of promoting measures aimed at holding the increase in the global average temperature to well below $2^{\circ} \mathrm{C}\left(1.5^{\circ} \mathrm{C}\right.$, if possible) above pre-industrial levels (UNFCCC 2016). Future emissions are uncertain, since they depend upon complex dynamic systems determined by demographic change, socioeconomic development, technological advance and political will. IPCC scenarios have provided projections for mean global temperature rise of between 1.8 and $4^{\circ} \mathrm{C}$ for the decade $2090-2099$ compared to $1980-1999$, with ranges between 1.1 and $6.4^{\circ} \mathrm{C}$ (Nakicenovic et al. 2007, IPCC 2007b) and increments of $1^{\circ} \mathrm{C}$ in mean global temperatures in the period 2016-2035 versus $1850-1900$, under high greenhouse gas emission scenarios (Stocker et al. 2013). Furthermore, for each extra degree of air temperature rise, the atmosphere can retain an additional $7 \%$ of water vapour (Breón et al. 2013).

The majority of analyses of long-term climate change have focussed upon changes in mean values, with less emphasis on extremes (Alexander et al. 2006). According to Easterling et al. (2000), climatic extremes can be categorised into two groups: those simply based upon climate statistics (very low and very high daily temperatures or large quantities of daily or monthly precipitation occurring over a year) or more complex extremes that do not necessarily occur each year at a given site (for example, drought, flood or hurricane). Changes in temperature and precipitation extremes have been reported (Nicholls 1995 , Karl and Knight 1998) and coincide with a world undergoing heating: diminution in cold extremes and a rise in hot extremes (Alexander et al. 2006, Easterling et al. 2000).

These changes would be expected to have a profound impact upon future crop yields, many of them deleterious (Worldbank 2013, Asseng et al. 2015, Zhao et al. 2017, IPCC 2018); in many areas of the world, climate change represents 32-39\% of the annual global variability of yield for wheat, corn, soybeans and rice (Ray et al. 2015). Hence it is necessary to study the future environments each crop could face if current climate trends persist or even worsen. For the current work, we have taken wheat as a study model, given its historical importance in Argentina.

Wheat, one of the most important cereals globally, is widely used for human and animal consumption. Worldwide, more than 200 million hectares are harvested, with China and India currently being the largest producers (FAO 2019). Argentina is one of the producing countries, contributing $2.4 \%$ of world production (FAO 2019), and an exporter, since current annual production (19 million tonnes in 2017/2018) far outstrips internal market requirements of 6 to 7 million tonnes (Ministry of Agriculture, Argentina, 2018). This, added to the proximity of Brazil and Mercosur, configures the country as an important exporter of the crop.

Temperature and rainfall affect wheat grain yield and quality, and the difference between the potential number of grains and the number of grains finally obtained strongly depends upon the environment. Increases in mean temperature accelerate the accumulation of grain dry matter, with an important reduction in the grain filling period, resulting in reduced interception of radiation by the crop and hence reduced final grain weight (Slafer et al. 2003), Water stress, as well as frosts, are very damaging in the boot stage due to the occurrence of pollen grain meiosis (Slafer et al. 2003). Water deficit also lowers grain weight by reductions in the rate of fill (Martos Núñez 2003) and its duration. Regarding final grain weight, temperature and water availability during grain fill are two of the factors of major incidence. 
Numerous studies have attempted to quantify wheat yield loss due to climate change. In Argentina, Abbate and Lázaro (2010) reported falls of 1.15 mg in potential grain weight (approximately $4 \%$ for a mean grain weight of $30 \mathrm{mg}$ ) for each degree Celsius increase in mean temperature during 35 days postanthesis; while in Europe, Moore and Lobell (2015), reported yield losses of 2.5\% for wheat, analysing long term trends of temperature and precipitation, and pointed to more detrimental effects in southern with respect to cooler regions (i.e. the United Kingdom and Ireland), which could not mitigate the impact with rainfall increase. Lobell et al. (2011), considering the whole growing season, reported a higher yield loss per degree increase, of 5.5\%; furthermore, according to Zhao et al. (2017), without $\mathrm{CO}_{2}$ fertilization, effective adaptation and genetic improvement, each degree-Celsius increase in global mean temperature would, on average, reduce global yields of wheat by $6.0 \pm 2.9 \%$ (Zhao et al. 2017), in concurrence with Asseng et al (2015), who also reported a figure of $6 \%$. Wheat yield losses have been observed in spite of the beneficial effects of $\mathrm{CO}_{2}$ for $\mathrm{C} 3$ species (Lobell et al. 2011), and at low latitudes, the climate change effect will be more negative, specially at a high level of warming with nitrogen $(\mathrm{N})$ stress, where there would be little true $\mathrm{CO}_{2}$ compensation for $\mathrm{C} 3$ species $($ Rosenzweig et al. 2014).

Schleussner et al. (2016) found substantial differences in impacts between $1.5^{\circ} \mathrm{C}$ and $2{ }^{\circ} \mathrm{C}$ warming with local yield reduction at middle and low latitudes, especially for wheat and maize. Trends are particularly severe for temperature in wheat evaluated at regional and national level (Lobell et al. 2011), with 6 and $8 \%$ of yield losses for $1.5^{\circ} \mathrm{C}$ and $2^{\circ} \mathrm{C}$ respectively for wheat (Schleussner et al. 2016).

Many studies analysing the umbral and maximum temperature have found negative effects on wheat yield and/or quality, and there is a certain consensus that temperatures above $30^{\circ} \mathrm{C}$ lower yield and quality through reductions in the rate of starch deposition (Jenner 1994) and in dough strength (Randall and Mo 1990).

Added to the above, events between anthesis and maturity condition quality characteristics of the crop since during this stage the molecular weight of the storage proteins, which are major determinants of quality, is rising (Fraschina 2017). Water stress events after flowering modify the rate of deposition of distinct grain components, negatively affecting yield and quality.

In Argentina, the long-term tendency for 1940-2007 of various agroclimatic indices showed heating, principally due to increments in the minimum temperature (Fernández Long et al. 2008), although for the most recent period (1975-2007), the tendency was weaker and in the opposite direction in some meteorological stations (Fernández Long et al. 2008). In the Pampas region, rises in annual minimum temperatures of $2^{\circ} \mathrm{C} / \mathrm{century}$ were reported during 1959-1998 (Rusticucci and Barrucand 2004). Additionally across this region, except for a small number of locations, the frost period decreased for the period 1940-2007, by a mean of 7 days per decade (Fernández Long et al. 2012).

Regarding precipitations, increases have been reported across the planet throughout the 20th century (Easterling et al. 2000). For example, the frequency of abundant precipitations has risen in South-Central USA and sectors of South America during 1950-2005, by 2 days per decade for the number of days/year, and the number of consecutive days without rain has reduced since 1960 (Alexander et al. 2006).

In the Pampas region of Argentina, Magrin et al. (2005) reported that mean precipitation rose by over 150 mm during the last thirty years of the 20th century compared to its beginning, especially between October and March. The changes varied over different months of the year, which could differentially affect different crop species. Marked precipitation increase has been observed in southern Brazil and northeastern Argentina from November to May (Berbery et al 2006; Re and Barros 2009). In north-eastern Argentina, the annual maximum amount of one-and five-day precipitation events increased from the 1970s to the 2000s; the higher frequencies of precipitation variability favoured extreme events post-2000 even during moderate extreme phases of the ENSO (Lovino et al 2018). Regarding the future, model projections have suggested that there could be an increase in the frequency of precipitation extremes over the La Plata Basin during future El Niño and La Niña events (Cavalcanti et al 2015).

In Argentina, climate studies have been carried out in the wheat region for mean temperatures (Fernández Long et al. 2008, 2012; Magrin et al. 2005, 2009), extreme temperatures in relation to frost (Fernández Long et al. 2012) and maximum and minimum temperatures (Rusticucci and Barrucand 2004), as well as on the impact of changes in temperature, radiation and precipitation on potential yields in wheat and other crops using simulators (Magrin et al. 2005, 2009). Although these studies provide a base for the current investigation, more exhaustive studies are necessary that also analyse changes in extreme rainfall variables, as proposed by Easterling et al. (2000), and temperature in relation to the umbral that prejudices wheat yield and quality, as well as the situation over recent years and differences within the wheat region. This type of study could serve as a model for the elaboration of perspectives for each cultivar and zone in particular.

The aim of the current work was to characterise the trend in the change in temperature and rainfall variables in two contrasting sites representative of the wheat growing region of Argentina. In contrast to Magrin et al. (2009), who studied changes in the centre of this region, we chose two sites, one towards the north of the region and the other towards the south, in order to discern whether there were differential effects of latitude, as has been suggested by modelling studies (Barros et al 1996).

\section{Materials And Methods}

\section{Sites studied}

Climatic data were analysed from the meteorological stations of Azul in the Province of Buenos Aires and Marcos Juárez (abbreviated as MJ) in the Province of Córdoba, located approximately 500 km apart (Fig. 1) Azul and MJ are found in different wheat growing subregions, namely IV and II North, respectively.

The climatic conditions in wheat growing region IV are adequate for crop development, with a cool temperate climate of long winters and annual rainfall of around $800-900 \mathrm{~mm}$, resulting in yields generally above the national average. Within this region, Azul itself has a temperate climate associated with the 
Pampas, with a mean annual temperature of $15^{\circ} \mathrm{C}$ and annual rainfall exceeding $900 \mathrm{~mm}$.

Subregion II North gives yields similar or slightly above the national average, where $\mathrm{MJ}$ itself has a humid temperate climate with maximum mean annual temperatures of $24^{\circ} \mathrm{C}$ and minimum mean annual temperatures of $11^{\circ} \mathrm{C}$, although minimum temperatures can fall below $-10^{\circ} \mathrm{C}$ and maximum temperatures above $41^{\circ} \mathrm{C}$. Annual rainfall is around $800 \mathrm{~mm}$.

The main sowing, anthesis and harvest dates are early June, October and mid-December for MJ and early July, towards the end of October / into November, and the end of December / early January for Azul, respectively.

\section{Data sets and variables evaluated}

Data of maximum (Tmax), minimum (Tmin), mean (Tmean) temperatures and rainfall were provided by the National Meteorological Service (Servicio Meteorológico Nacional, SMN).

The original weather station in Azul (A, 36 $\left.45^{\circ} \mathrm{S} 59^{\circ} 50^{\prime} \mathrm{O} 132 \mathrm{~m}\right)$ was disactivated in 1994 and a new station was immediately activated $10 \mathrm{~km}$ away (B, $36^{\circ}$ $50 S 59$-500 $147 \mathrm{~m}$ ). The data from these (original station: 1/1/1931-15/12/1994 and new station: 16/12/1994-28/2/2015) were cross-checked with a third station (Tandil aero, $37^{\circ} 14^{\prime} \mathrm{S} 59^{\circ} 20^{\prime} \mathrm{O}$ ), in order to verify that the $10 \mathrm{~km}$ distance had not significantly affected the measurements; this procedure showed that the original and new stations could be considered as one and the same.

The data from MJ were provided by station $87467\left(32^{\circ} 42 \mathrm{~S} 62^{\circ} 100\right)$ and covered the period 1/7/1952 to 28/02/2015.

The study of the monthly temperature series included Tmax, Tmin ,Tmean and daily thermal range (DTR). The duration of the period in each year with minimum temperatures equal to or below $0^{\circ} \mathrm{C}\left(\mathrm{Du} \mathrm{T} \leq 0^{\circ} \mathrm{C}\right)$ was also determined. Extreme monthly temperature values included maximum $(\mathrm{Vmax})$ and minimum (Vmin) temperatures, number of days with temperatures equal to or above $30^{\circ} \mathrm{C}\left({ }^{*}\right)\left(\mathrm{ND} \mathrm{T} \geq 30^{\circ} \mathrm{C}\right)$ and accumulated degrees above $30^{\circ} \mathrm{C}\left({ }^{*}\right)\left({ }^{\circ} \mathrm{C} \mathrm{T} \otimes\right.$ $30^{\circ} \mathrm{C}$ ). The rainfall monthly variables (which included rainfall of less than $1 \mathrm{~mm}$ ) were number of days with precipitation (ND PP) and total precipitation (mmt $\mathrm{PP})$. Extreme rainfall variables as number of days with precipitation equal to or below $5 \mathrm{~mm}\left({ }^{*}\right)(\mathrm{ND} P \mathrm{PP} \leq 5 \mathrm{~mm})$, equal to or above $50.8 \mathrm{~mm}\left({ }^{\star}\right)(\mathrm{ND}$ PP $\geq 50.8$ $\mathrm{mm}$ ) and equal to or above $101.6 \mathrm{~mm}\left({ }^{\star}\right)(\mathrm{ND} P P \geq 101.6 \mathrm{~mm}$ ) were included according to Easterling et al. (2000) (2 and 4 inches equal to 50.8 and 101.6 $\mathrm{mm}$, respectively). Accumulated precipitation from September to December each year (mm PP4 months) were also included. Variables above marked with with * included many values equal to 0 due to the criteria used for their construction.

Hence 15 variables, to which prior data quality control was applied, were analysed for September, October, November and December for the whole period of years for each site (Azul: 1931-2014; MJ:1952-2014); these months were chosen since they cover the critical months in the wheat cycle for yield and quality determination.

\section{Data analysis}

\section{Analysis of each site}

Linear regression was applied to all variables over time from both sites using the software Infostat version 2016 (Di Rienzo et al. 2016$)$. The periods analysed $(15,62$ and 83 years) allowed the removal of the Niño effect and volcanic activity, which are observed during periods of less than five years, as well as the effect of the solar cycle observed over periods below eleven years (De Saedeleer 2016). The regression analyses showed homogeneous distribution of residuals; nonetheless, since these are sensitive to the seasonality of the data, the analysis used to assess trends was the Mann-Kendall trend test (MK) (Mann 1945, Kendall 1975) (software RStudio 0.99.902 2009-2016), since it lacks the limitations of regression analysis and hence makes the predictions more robust, being a non-parametric test that works for all types of distribution providing there is no serial correlation (Blain 2013). For this last analysis, year was considered as a factor and the remaining variables considered as time series. From the MK analysis, the value of the statistic tau ( $\tau$ ) was obtained, a coefficient indicative of a correlation between variables and the two-tailed probability value.

Differences between sites

The sites were analysed by principal components (PC) for the whole period of years in common (1952-2014) and for the first fifteen years of the current century (2000-2014).

Additionally, the linear regression gradients from the whole period for each site for those cases where the value of $p$ from MK was significant were compared by t-test (see Eq. 1).

Equation $1: \frac{X 1-X 2}{\sqrt{(\text { error } 1)^{2}}-\sqrt{(\text { error } 2)^{2}}}$

Where $\mathrm{X} 1$ and $\mathrm{X} 2$ are the gradients from sites 1 and 2, respectively. Significance level $5 \%$. Impact of the last years on the general tendency for the constructed variables

The extreme variables ND T $\geq 30^{\circ} \mathrm{C},{ }^{\circ} \mathrm{C} \geq 30^{\circ} \mathrm{C}$, ND PP $\leq 5 \mathrm{~mm}$, ND PP $\geq 50,8 \mathrm{~mm}$ and ND PP $\geq 101,6 \mathrm{~mm}$ were analysed as proportions, evaluating the significance of the proportion that represented the period 2000-2014 against the period 1952-2014 using the software STATISTICA (StatSoft Inc. 2004), which computes the level of significance for the difference between the two proportions according to Eq. 2. The value of $p$ was calculated based upon the value of $t$ for the respective comparison.

Equation 2:

$$
|\mathrm{t}|=\frac{\sqrt{[(N 1 * N 2) /(N 1+N 2)] *|p 1-p 2|}}{\sqrt{(p * q)}}
$$


Where $\mathrm{p} 1$ is the proportion of the first sample (Azul); $\mathrm{p} 2$ is the proportion of the second sample (MJ); N1 is the size of the first sample (Azul); N2 is the size of the second sample $(\mathrm{MJ}) ; \mathrm{p}=\left(\mathrm{p} 1{ }^{*} \mathrm{~N} 1+\mathrm{p} 2 * \mathrm{~N} 2\right) /(\mathrm{N} 1+\mathrm{N} 2) ; \mathrm{q}=1-\mathrm{p}$ and the degrees of freedom are calculated as $(\mathrm{N} 1+\mathrm{N} 2)-2$.

10,50 and 100 years future projections for both sites

Using the regression equations for the complete period of each site, estimations were made of future projections for the next 10,50 and 100 years for the variables with significant trends. Projections were also made of future wheat yield losses due to global heating, based upon an estimated $6 \%$ loss in yield per ${ }^{\circ} \mathrm{C}$ increase in mean temperature (IPCC 2018, Zhao et al. 2017, Asseng et al. 2015).

\section{Results}

\section{Analysis of temperature}

The monthly mean temperature variables increased significantly over the years in certain months at both sites (Table 1): in Azul, the maximum daily temperatures monthly mean (Tmax) in September and October (Fig. 3A), the minimum daily temperatures monthly mean (Tmin) in November and December and the mean daily temperatures monthly mean (Tmean) in all four months (October Fig. 3C); and in Marcos Juárez (MJ), Tmax in September, October (Fig. 3B) and November, Tmin in October and November and Tmean in September, October (Fig. 3D) and November. With the exception of Tmax and Tmean in December, the regression coefficients in MJ were consistently higher than those in Azul. For example, the regression coefficients for Tmax, Tmin and Tmean for October in MJ were approximately three-fold higher than those in Azul (Tmin non-significant in Azul). These observations imply that, in general for the temperature variables, the rate of climate change in $\mathrm{MJ}$ was higher than that in Azul 
Table 1

Regression coefficients and Mann Kendall tests for the complete period in Azul and Marcos Juárez for the mean and extreme temperature and rainfall variables, and comparison between regression coefficients where these were significant at both sites. $\mathrm{b}-$ regression coefficient. * and ** indicate significant differences at 0.05 and 0.01 , respectively. $\mathrm{N}$ - no days observed with daily rainfall $\geq 101.6 \mathrm{~mm}$ for these months (September in Azul and November in Marcos Juárez)

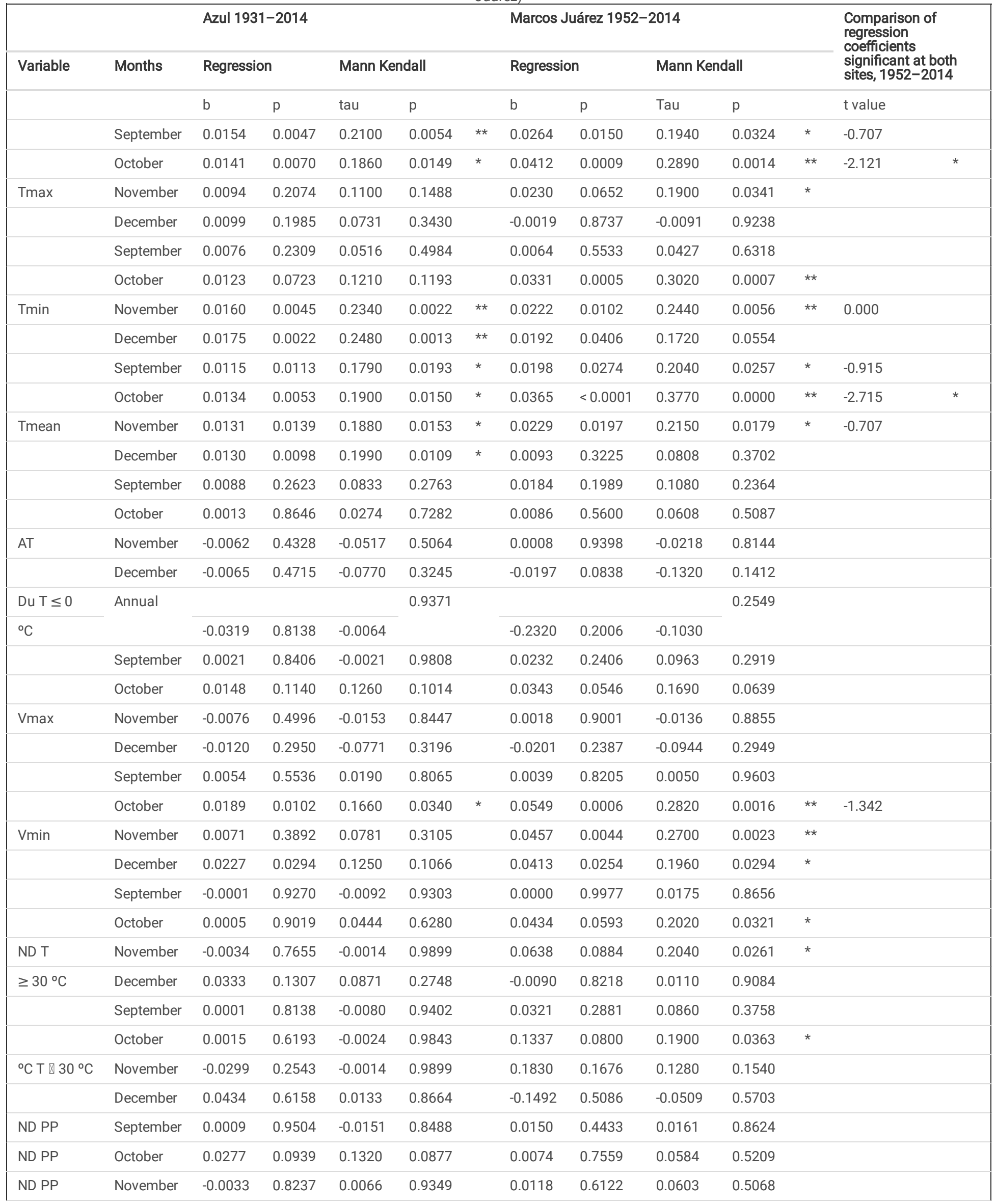




\begin{tabular}{|c|c|c|c|c|c|c|c|c|c|c|c|}
\hline \multirow{3}{*}{$\begin{array}{l}\text { Variable } \\
\text { ND PP }\end{array}$} & \multirow{3}{*}{$\begin{array}{l}\text { Months } \\
\text { December }\end{array}$} & \multicolumn{4}{|c|}{ Azul 1931-2014 } & \multicolumn{5}{|c|}{ Marcos Juárez 1952-2014 } & \multirow{3}{*}{$\begin{array}{l}\text { Comparison of } \\
\text { regression } \\
\text { coefficients } \\
\text { significant at bott } \\
\text { sites, 1952-2014 }\end{array}$} \\
\hline & & \multicolumn{2}{|c|}{ Regression } & \multicolumn{2}{|c|}{ Mann Kendall } & \multicolumn{2}{|c|}{ Regression } & \multicolumn{2}{|c|}{ Mann Kendall } & & \\
\hline & & -0.0166 & 0.1807 & -0.0860 & 0.2751 & -0.0014 & 0.9479 & -0.0294 & 0.7532 & & \\
\hline $\mathrm{mmt} P \mathrm{PP}$ & September & 0.0943 & 0.6027 & 0.0238 & 0.7514 & 0.0315 & 0.9224 & -0.0159 & 0.8588 & & \\
\hline mmt PP & October & 0.0150 & 0.9591 & 0.0547 & 0.4669 & 0.3776 & 0.3822 & 0.0148 & 0.8681 & & \\
\hline $\mathrm{mmt} P \mathrm{PP}$ & November & 0.2920 & 0.2282 & 0.1070 & 0.1518 & 0.3126 & 0.3495 & 0.1030 & 0.2355 & & \\
\hline \multirow[t]{2}{*}{$\mathrm{mmt} P \mathrm{PP}$} & December & 0.0103 & 0.9603 & -0.0409 & 0.5873 & 0.7340 & 0.1765 & 0.1300 & 0.1402 & & \\
\hline & \multirow{2}{*}{$\begin{array}{l}\text { September } \\
\text { to } \\
\text { December }\end{array}$} & & & & & & & & & & \\
\hline \multirow{2}{*}{$\begin{array}{l}\mathrm{mm} \\
\text { PP4months }\end{array}$} & & 0.4127 & 0.3809 & 0.0708 & 0.3452 & 15.233 & 0.1036 & 0.1710 & 0.0489 & * & \\
\hline & September & -0.0029 & 0.7850 & -0.0110 & 0.8925 & 0.0189 & 0.2081 & 0.0807 & 0.3796 & & \\
\hline ND PP $\leq$ & October & 0.0155 & 0.2378 & 0.0912 & 0.2484 & 0.0127 & 0.4562 & 0.0618 & 0.5032 & & \\
\hline \multirow[t]{3}{*}{$5 \mathrm{~mm}$} & November & -0.0076 & 0.5162 & -0.0294 & 0.7104 & 0.0104 & 0.4754 & 0.0636 & 0.4897 & & \\
\hline & December & -0.0121 & 0.2388 & -0.0687 & 0.3871 & -0.0247 & 0.0959 & -0.1530 & 0.1010 & & \\
\hline & September & 0.0023 & 0.0851 & 0,115 & 0,2031 & -0.0019 & 0.3860 & $-0,0914$ & 0,3877 & & \\
\hline \multirow{4}{*}{$\begin{array}{l}\mathrm{ND} P P \geq \\
50.8 \mathrm{~mm}\end{array}$} & October & -0.0025 & 0.3475 & $-0,045$ & 0,6142 & 0.0048 & 0.2291 & 0,143 & 0,1677 & & \\
\hline & November & 0.0011 & 0.6018 & 0,0481 & 0,5941 & 0.0011 & 0.7248 & 0,0372 & 0,7275 & & \\
\hline & December & 0.0020 & 0.1902 & 0,119 & 0,1909 & 0.0007 & 0.8697 & 0,0025 & 0,9874 & & \\
\hline & September & $\mathrm{N}$ & $\mathrm{N}$ & $\mathrm{N}$ & $\mathrm{N}$ & 0.0014 & 0.1114 & 0,167 & 0,1171 & & \\
\hline \multirow{3}{*}{$\begin{array}{l}\text { ND PP } \geq \\
101.6 \mathrm{~mm}\end{array}$} & October & -0.0007 & 0.1685 & $-0,125$ & 0,1735 & 0.0014 & 0.0993 & 0,172 & 0,1047 & & \\
\hline & November & -0.0006 & 0.2259 & $-0,11$ & 0,2317 & $\mathrm{~N}$ & $\mathrm{~N}$ & $\mathrm{~N}$ & $\mathrm{~N}$ & & \\
\hline & December & 0.0001 & 0.9013 & 0,0114 & 0,9169 & 0.0009 & 0.5751 & 0,0603 & 0,5821 & & \\
\hline
\end{tabular}

In contrast, the daily thermal range monthly mean (DTR) and the duration of the period with minimum temperatures equal to or below $0^{\circ} \mathrm{C}\left(\mathrm{Du} \mathrm{T} \leq 0{ }^{\circ} \mathrm{C}\right)$ showed no significant changes at either site (Table 1).

From these results it appears that the variables in general are by no means showing similar changes over the study period; further evidence for this is provided by the analysis of variables focused upon more extreme temperature phenomena: the maximum monthly temperature value (Vmax), the minimum monthly temperature value (Vmin), the number of days per month with temperatures equal to or above $30^{\circ} \mathrm{C}\left(\mathrm{ND} \mathrm{T} \geq 30^{\circ} \mathrm{C}\right)$ and the accumulated degrees per month above $30^{\circ} \mathrm{C}\left({ }^{\circ} \mathrm{C} \mathrm{T} \otimes 30^{\circ} \mathrm{C}\right)$ (Table 1). While no significant regressions were observed for Vmax, Vmin did show such regressions, although in Azul only in October (albeit with a regression coefficient higher than those observed for the temperature variables mentioned above); in contrast, in $\mathrm{MJ}$, the regressions were significant in October, November and December, with gradients higher than those observed in Azul. Just as in the case of the variables Tmax, Tmin and Tmean mentioned above, this again implies that the rate of climate change in $\mathrm{MJ}$ is generally more pronounced that that in Azul.

Further evidence for differences between sites was provided by ND T $\geq 30^{\circ} \mathrm{C}$ and ${ }^{\circ} \mathrm{C} \mathrm{T} \otimes 30^{\circ} \mathrm{C}$, for which significant regressions were only observed in $\mathrm{MJ}$, in October and November for the former variable and in October for the latter, with regression coefficients amongst the highest observed for all the variables analysed. Hence there seems to be no appreciable climate change for these characters in Azul, in contrast to MJ, where the rate of change was considerable.

In conclusion, of all the thirty-three combinations of comparisons carried out (eight variables for which four months were analysed per variable, plus one variable (Du T $\leq 0^{\circ} \mathrm{C}$ ) analysed over the four months as a whole) (Table 1), there were (i) seven combinations (Tmax Septembers, Tmax Octobers, Tmin Novembers, Tmean Septembers, Tmean Octobers, Tmean Novembers and Vmin Octobers) that gave significant, positive, regression coefficients in both Azul and $\mathrm{MJ}$, where the magnitude of the coefficient in MJ was always numerically greater than in Azul, including significantly so for two of them (Tmax Octobers and Tmean Octobers), according to application of Eq. 1 (defined in Materials and Methods) (Table 1); (ii) seven combinations (Tmax Novembers, Tmin Novembers, Vmin Novembers, Vmin Decembers, ND T $\geq 30^{\circ} \mathrm{C}$ Octobers, ND T $\geq 30^{\circ} \mathrm{C}$ Novembers and ${ }^{\circ} \mathrm{C} \mathrm{T} \otimes 30^{\circ} \mathrm{C}$ Octobers) that gave significant, positive, regression coefficients in $\mathrm{MJ}$, but non-significant regressions in Azul, where the magnitude of the coefficient in MJ was, as would be expected, always numerically higher than in Azul; and (iii) only two combinations (Tmin Decembers and Tmean Decembers) that opposed these trends, since they gave significant, positive, regression coefficients in Azul, but non-significant regressions in MJ. These results imply that, for those combinations showing significant climate change, the rate of change was, with notably few exceptions, considerably higher in MJ than in Azul.

\section{Analysis of rainfall}

Of all the rainfall variables analysed (Table 1), only the regression of the accumulated precipitation from September to December each year (mm PP4 months) in MJ was significant, showing that, firstly, there was generally relatively little climate change over the years for rainfall, and, secondly, where there was 
change, this was only observed in MJ.

Regarding variables associated with extreme rainfall phenomena, i.e. the number of days with precipitation equal to or below $5 \mathrm{~mm}$ per month (ND PP $\leq 5$ $\mathrm{mm}$ ), the number of days with precipitation equal to or above $50.8 \mathrm{~mm}$ per month (ND PP $\geq 50.8 \mathrm{~mm}$ ) and the number of days with precipitation equal to or above $101.6 \mathrm{~mm}$ (ND PP $\geq 101.6 \mathrm{~mm}$ ) (NB: the distribution of the residual errors was non-random for the latter two variables), no significant differences were found over the months analysed for either site, again supporting the idea that there was relatively little climate change observed for rainfall (Table 1 ).

\section{Multivariate comparison between sites}

Having provided evidence that for individual variables the sites showed notable differences in their rates of climate change, we applied principal components (PC) analysis to see to what extent the sites differed when the variables were considered as a whole across the whole period (1952-2014) (Fig. 2).

The sites clearly differed for PC 1 since all data points had higher values for PC 1 than do those in Azul, component positively correlated with the temperature variables Tmin, Tmean and Tmax, together covering the four months under study, and negatively correlated with the duration of the period with temperatures equal to or below $0^{\circ} \mathrm{C}\left(\mathrm{Du} \mathrm{T} \leq 0^{\circ} \mathrm{C}\right)$, albeit that the correlations were low in magnitude (Table 2).

Table 2

Loadings of the 18 main variables that most discriminate between Azul and Marcos Juárez in the periods $1952-2014$ and $2000-2014$.

\begin{tabular}{|c|c|c|c|c|c|}
\hline $1952-2014$ & & & $2000-2014$ & & \\
\hline Variables & e1 & e2 & Variables & e1 & e2 \\
\hline $\mathrm{Du} T \leq 0^{\circ} \mathrm{C}$ & -0.14 & -0.18 & $\mathrm{Du} \mathrm{T} \leq 0^{\circ} \mathrm{C}$ & -0.16 & -0.18 \\
\hline DTR December & -0.07 & -0.28 & ND PP $\leq 5 \mathrm{~mm}$ November & -0.12 & $-8.40 \mathrm{E}-05$ \\
\hline ND PP $\leq 5 \mathrm{~mm}$ November & -0.06 & 0.07 & ND PP September & -0.1 & 0.18 \\
\hline mmt PP September & -0.05 & 0.09 & mmt PP September & -0.1 & 0.2 \\
\hline ND PP October & -0.05 & 0.2 & ND PP October & -0.1 & 0.19 \\
\hline $\mathrm{ND} P P \leq 5 \mathrm{~mm}$ October & -0.05 & 0.14 & ND PP $\leq 5 \mathrm{~mm}$ October & -0.1 & 0.14 \\
\hline ND PP November & -0.05 & 0.16 & DTR December & -0.1 & -0.22 \\
\hline ND PP September & -0.04 & 0.13 & $\begin{array}{l}\text { ND PP } \geq 50.8 \mathrm{~mm} \\
\text { September }\end{array}$ & -0.07 & 0.13 \\
\hline $\begin{array}{l}\text { ND PP } \geq 50.8 \mathrm{~mm} \\
\text { September }\end{array}$ & -0.02 & 0.02 & ND PP November & -0.07 & 0.14 \\
\hline Tmean December & 0.2 & -0.04 & Vmax September & 0.2 & 0.01 \\
\hline Tmean September & 0.21 & 0.05 & Tmax November & 0.2 & -0.1 \\
\hline Tmax October & 0.21 & -0.01 & Tmin November & 0.2 & 0.04 \\
\hline Tmax November & 0.21 & -0.11 & ND $\mathrm{T}>30^{\circ} \mathrm{C}$ November & 0.2 & -0.1 \\
\hline Tmin November & 0.21 & 0.07 & Tmin December & 0.2 & 0.09 \\
\hline Tmin December & 0.21 & 0.08 & Tmax September & 0.21 & -0.01 \\
\hline Tmax September & 0.22 & -0.02 & Tmax October & 0.21 & 0.01 \\
\hline Tmean October & 0.22 & 0.08 & Tmean October & 0.21 & 0.11 \\
\hline
\end{tabular}

For the period 2000-2014, PC 1 was related to temperature variables and Du T $\leq 0^{\circ} \mathrm{C}$ in a similar way to that observed for the whole period, as well as to variables associated with extreme events (Vmax and ND T>30 ${ }^{\circ} \mathrm{C}$, and there was also a slight tendency to be related to rainfall variables (Table 2).

In general, the sites were not discriminated by PC 2 (Fig. 2) or any other PC (results not shown).

Taken as a whole, together with the results for individual variables described earlier, the data confirm that MJ is clearly the warmer of the two sites (for the variables correlated with PC 1).

Additionally, the points for the years 2000-2014 for MJ are slightly displaced towards higher values of PC 1 than the remaining years at this site, whereas this is not so for Azul, implying that the more recent years at $\mathrm{MJ}$ are warmer than previous years and indicating a possible acceleration in climate change at this site for the variables correlated with PC 1.

Impact of the period $2000-2014$

Following this lead, analysis of the frequency of extreme temperature and rainfall events for the period 2000-2014 compared with that for 1952-2014 (Table 3) showed that in the more recent period it was found that, at both sites, there were increases in variables associated with the $30^{\circ} \mathrm{C}$ limit (ND T $\geq 30^{\circ} \mathrm{C}$ and ${ }^{\circ} \mathrm{C} \mathrm{T}>30^{\circ} \mathrm{C}$ ) in October. Additionally, all events of rainfall of $101.6 \mathrm{~mm}$ or more (ND PP $\geq 101.6 \mathrm{~mm}$ ) have been recorded in MJ in September and October during more recent years (Table 3 ). 
Table 3: Proportions explained for the most recent 15 years for the constructed variables compared to the $1952-2014$ series.

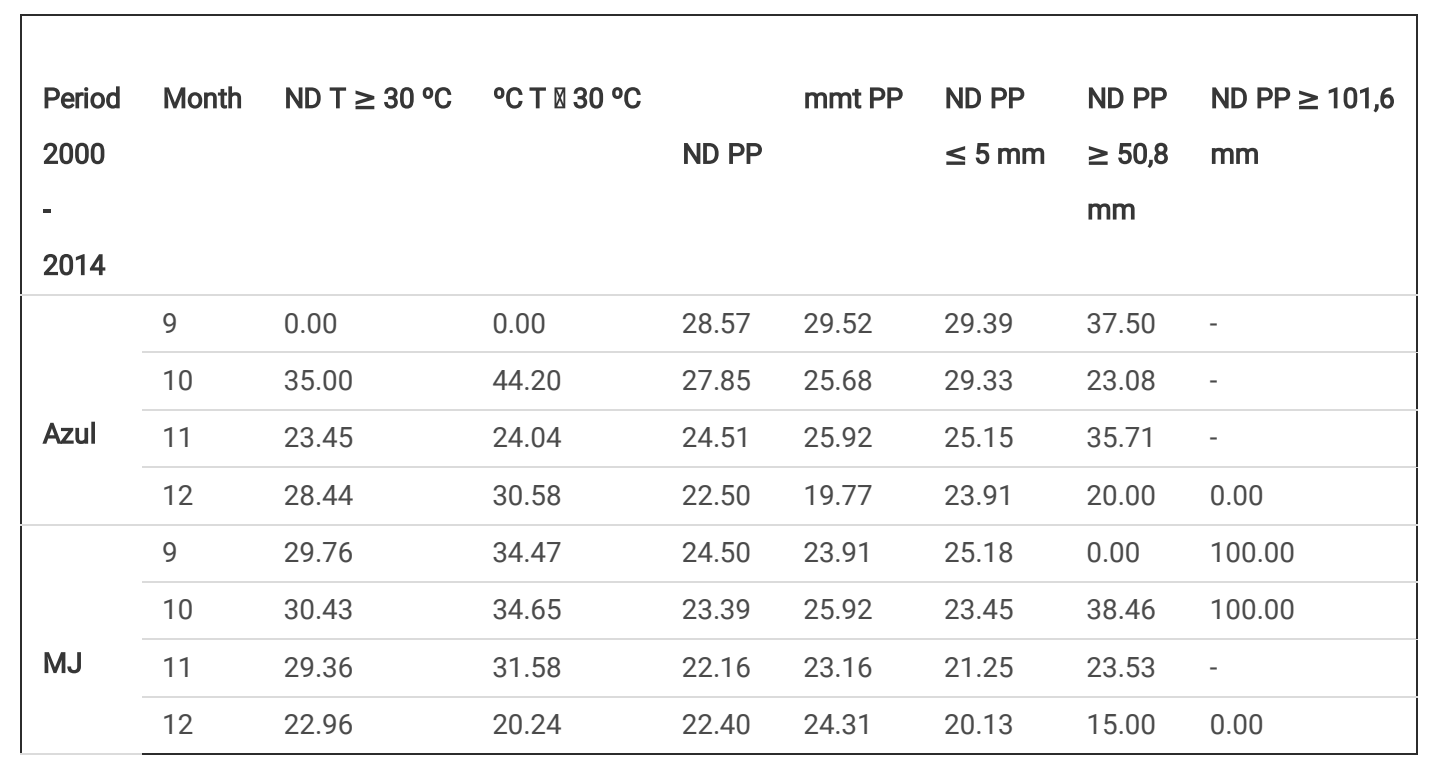

The analysis of differences between proportions (Eq. 2) of the first fifteen years of the century compared to the whole period showed that the temperature extremes (ND T $\geq 30^{\circ} \mathrm{C}$ and ${ }^{\circ} \mathrm{C} \geq 30^{\circ} \mathrm{C}$ ) had become more frequent at both sites in September, differentially so (P value of 0.03 and 0.02 , respectively).

Regarding rainfall extremes, this was also observed for ND PP $\geq 50.8 \mathrm{~mm}$ for September (P value of 0.01).

Hence climate change appears to have become more marked in recent years compared to previous ones, seemingly more so in MJ than in Azul.

\section{Future projections}

From the above results, twenty-four of the variables analysed were found to be changing significantly and we made projections over the next 10,50 and 100 years based upon our regression coefficients over the whole period (Table 4). Given that the changes appear to have accelerated over the first fifteen years of the century, these will likely be underestimates of the expected changes, which in any case will, of course, depend upon future greenhouse gas emission scenarios and a host of other factors. 
Table 4

Current and future $(10,50$ and 100 years) values for the variables giving significant regressions and Mann Kendall tests, and projected \% yield losses at 100 years for Tmean assuming $6 \%$ fall in yield

\begin{tabular}{|c|c|c|c|c|c|}
\hline \multirow[t]{2}{*}{ Variable } & \multirow{2}{*}{$\begin{array}{l}\text { Value in } \\
2014\end{array}$} & \multicolumn{3}{|c|}{ Projected value at: } & \multirow{2}{*}{$\begin{array}{l}\text { Projected \% yield loss } \\
\text { at } 100 \text { years }\end{array}$} \\
\hline & & $\begin{array}{l}10 \\
\text { years }\end{array}$ & $\begin{array}{l}50 \\
\text { years }\end{array}$ & $\begin{array}{l}100 \\
\text { years }\end{array}$ & \\
\hline $\begin{array}{l}\text { Tmean Septembers } \\
\text { Azul }\end{array}$ & 13.04 & 13.16 & 13.62 & 14.19 & 6.90 \\
\hline Tmean Octobers Azul & 16.12 & 16.25 & 16.79 & 17.46 & 8.04 \\
\hline $\begin{array}{l}\text { Tmean Novembers } \\
\text { Azul }\end{array}$ & 17.78 & 17.91 & 18.44 & 19.09 & 7.86 \\
\hline $\begin{array}{l}\text { Tmean Decembers } \\
\text { Azul }\end{array}$ & 20.94 & 21.07 & 21.59 & 22.24 & 7.80 \\
\hline $\begin{array}{l}\text { Tmean Septembers } \\
\text { MJ }\end{array}$ & 15.90 & 16.10 & 16.89 & 17.88 & 11.88 \\
\hline Tmean Octobers MJ & 20.31 & 20.68 & 22.14 & 23.96 & 21.90 \\
\hline $\begin{array}{l}\text { Tmean Novembers } \\
\text { MJ }\end{array}$ & 20.61 & 20.84 & 21.76 & 22.90 & 13.74 \\
\hline Tmin Octobers MJ & 12.76 & 13.09 & 14.42 & 16.07 & \\
\hline Tmin Novembers Azul & 11.15 & 11.31 & 11.95 & 12.75 & \\
\hline Tmin Novembers MJ & 12.78 & 13.00 & 13.89 & 15.00 & \\
\hline Tmin Decembers Azul & 13.46 & 13.64 & 14.34 & 15.21 & \\
\hline $\begin{array}{l}\text { Tmax Septembers } \\
\text { Azul }\end{array}$ & 18.12 & 18.27 & 18.89 & 19.66 & \\
\hline Tmax Octobers Azul & 22.25 & 22.39 & 22.96 & 23.66 & \\
\hline Tmax Septembers MJ & 23.35 & 23.61 & 24.67 & 25.99 & \\
\hline Tmax Octobers MJ & 27.86 & 28.27 & 29.92 & 31.98 & \\
\hline Tmax Novembers MJ & 28.45 & 28.68 & 29.60 & 30.75 & \\
\hline Vmin Octobers Azul & 2.30 & 2.49 & 3.25 & 4.19 & \\
\hline Vmin Octovers MJ & 5.00 & 5.55 & 7.75 & 10.49 & \\
\hline Vmin Novembers MJ & 6.20 & 6.66 & 8.49 & 10.77 & \\
\hline Vmin Decembers MJ & 6.00 & 6.41 & 8.07 & 10.13 & \\
\hline $\begin{array}{l}\mathrm{ND} \mathrm{T} \geq 30^{\circ} \mathrm{C} \\
\text { Octobers MJ }\end{array}$ & 8.00 & 8.43 & 10.17 & 12.34 & \\
\hline $\begin{array}{l}\mathrm{ND} T \geq 30^{\circ} \mathrm{C} \\
\text { Novembers } \mathrm{MJ}\end{array}$ & 14.00 & 14.64 & 17.19 & 20.38 & \\
\hline $\begin{array}{l}{ }^{\circ} \mathrm{C} T \otimes 30^{\circ} \mathrm{C} \text { Octobers } \\
\mathrm{MJ}\end{array}$ & 37.50 & 38.84 & 44.19 & 50.87 & \\
\hline $\mathrm{mm} \mathrm{PP}_{4 \text { meses }} \mathrm{MJ}$ & 356.90 & 372.13 & 433.07 & 509.23 & \\
\hline
\end{tabular}

For example, October and November maximum temperatures in $\mathrm{MJ}$ are expected to reach around $30^{\circ} \mathrm{C}$ by 2064 and a further $2^{\circ} \mathrm{C}$ in $0 c t o b e r$ or $0.75^{\circ} \mathrm{C}$ in November by 2114 (Table 4). Furthermore, within the next fifty years, the number of days with temperatures equal to or above this temperature could rise by $27 \%$ in October and $23 \%$ in November, accumulating $6.68^{\circ} \mathrm{C}$ above the current value for October (Table 4 ).

Regarding Tmean, increases of between 1.15 and $1.34^{\circ} \mathrm{C}$ are expected for Azul and between 1.98 and $3.65^{\circ} \mathrm{C}$ for $\mathrm{MJ}$, depending on the month involved; i.e. considerably higher increases are expected for $\mathrm{MJ}$ than for Azul. Assuming a $6 \%$ loss in yield per ${ }^{\circ} \mathrm{C}$ increase in Tmean, as proposed by Asseng et al. (2015), Zhao et al. (2017) and IPCC (2018), these increases translate into potential yield losses of between 6.90 and $8.04 \%$ for Azul and between 11.88 and 21.90 for MJ, again depending upon the month (Table 4). The means of these figures are approximately $8 \%$ for Azul and $16 \%$ for $\mathrm{MJ}$; hence expected yield losses for $\mathrm{MJ}$ are considerably higher than, possibly double, those expected for Azul.

\section{Discussion}

The analysis of historical climate data from Azul, Province of Buenos Aires, and Marcos Juárez, Province of Córdoba, sites in two contrasting zones representing the wheat growing region of Argentina, allowed the characterisation of past and possible future changes in temperature and rainfall variables during the months in which wheat is grown in this country. Changes in mean and extreme temperature and rainfall variables observed were largely consistent 
with those reported in the relevant literature (Alexander et al. 2006, Nakicenovic et al. 2007, IPCC 2007b, Trenberth et al. 2007, Fernández Long et al. 2008, Stocker et al. 2013).

\section{Considerations for each site}

\section{Mean temperature values}

The maximum temperatures (Tmax) in September and October in Azul and MJ have increased significantly over the years (Table 1), more intensely so in the latter site, where besides significant increases were observed in November. If the observed rates continue, increases of $0.15^{\circ} \mathrm{C}$ and $0.25^{\circ} \mathrm{C}$ per decade in September in Azul and MJ, respectively, would be expected, higher than those reported by Magrin et al. (2009) for the Pampas region for this month (0.07 between 1930 and 2000, and 0.00 between 1970 and 2000). The expected increases for October are, on the other hand, similar to those reported in the same study (for Azul, $0.14^{\circ} \mathrm{C}$ in our study against $0.13^{\circ} \mathrm{C}$ between 1930 and 2000 , and, for $\mathrm{MJ}, 0.41^{\circ} \mathrm{C}$ in our study against $0.43^{\circ} \mathrm{C}$ between 1970 and 2000 ). For November, the projections for $\mathrm{MJ}\left(0.23^{\circ} \mathrm{C}\right)$ are higher than those indicated in the same study for $1930-2000$ and lower than those estimated for $1970-2000$ ( 0.00 and $0.47^{\circ} \mathrm{C}$, respectively).

Regarding the minimum temperatures (Tmin), these increased significantly over the years in November at both sites (Table 1), and additionally in December at Azul and in October in $\mathrm{MJ}$. If the rates of change continue, increases in October in $\mathrm{MJ}$ of $0.03^{\circ} \mathrm{C}$ per decade would be expected, similar to those from the Magrin et al. (2009) study for $1930-2000\left(0.36^{\circ} \mathrm{C}\right)$, although less than those from the same study for $1970-2000\left(0.58^{\circ} \mathrm{C}\right)$. The increases expected for November for Azul and $\mathrm{MJ}$ are less than those previously reported in this study $\left(0.16^{\circ} \mathrm{C}\right.$ in $\mathrm{Azul}$ and $0.22^{\circ} \mathrm{C}$ in $\mathrm{MJ}$ against $0.39^{\circ} \mathrm{C}$ between 1970 and 2000 , and $0.61^{\circ} \mathrm{C}$ between 1970 and 2000) (Table 1). The increments in this variable in October and November in MJ (Table 4) are notably greater than those projected by Rusticucci and Barrucand (2004) of $2^{\circ} \mathrm{C}$ per 100 years for the Pampas region. Furthermore, increments of $0.18^{\circ} \mathrm{C}$ per decade are projected for Azul.

The mean temperatures (Tmean) have also risen during the months analysed at both sites over the years, except for December in MJ. These rises are consistent with those reported by Stocker et al. (2013) for the 20th Century. The rises were more marked in MJ than in Azul (Table 1). If these rates of rise continue, increases in Azul of $0.12^{\circ} \mathrm{C}$ per decade in September and of $0.13^{\circ} \mathrm{C}$ in October, November and December would be expected, while in MJ rises of 0.2 , 0.37 and $0.23^{\circ} \mathrm{C}$ per decade for September, October and November, respectively, would be expected. It is interesting to note that in October, the differences between the sites for this variable were threefold and the expected increases for MJ almost duplicated those stipulated by the IPCC in their fourth report for the decades $2007-2017$ and $2007-2017\left(0.2^{\circ} \mathrm{C}\right.$ per decade for a range of emission scenarios, including for those where the concentrations of greenhouse gas and aerosols stayed at year 2000 values, IPCC 2007b).

The increases in mean temperatures found, due to the rises in maximum temperatures in September and October, and in minimum temperatures in November and December, could reduce potential yield in wheat (Magrin and Travaso 2002, Nuñez et al. 2008) due to the shortened grain fill period not compensated for by higher rates of filling, as affirmed by Stone and Savin (1999) for temperatures above $15^{\circ} \mathrm{C}$. Elevated temperatures reduce the capture of resources, as well as affecting the partition of biomass to harvestable organs (Magrin et al. 2005). As a consequence of these effects, grain size and yield are reduced.

The temperature rises in October, November and December might imply possible deleterious effects on potential yield and quality at both sites, in spite of the different sowing dates between sites, due to current growing temperatures being close to optimal. Furthermore, the changes are generally more severe in MJ than in Azul when the data is considered as a whole. Magrin et al. (2009), for example, reported wheat yield reductions of $28.3 \mathrm{~kg} / \mathrm{ha}$ per year (0.33\%) between 1930 and 2000 , and $52.7 \mathrm{~kg} / \mathrm{ha}$ per year $(0.56 \%)$ between 1970 and 2000 . The increases in minimum temperatures in October and November together explained $65 \%$ of the reduction in yield between 1930 and 2000 , which implies losses of $0.6 \mathrm{t} / \mathrm{ha}$, almost $7 \%$ of yield potential, for each ${ }^{\circ} \mathrm{C}$ rise in Tmin during these months (Magrin et al. 2009). This is a warning sign for food safety, because yield losses are expected to occur in spite of the potential beneficial effects of increased $\mathrm{CO}_{2}$ concentration (Lobell et al. 2011).

Further consideration of the possible consequences for yield of temperature rise at the two sites are given later in the Discussion.

Although better use of increased $\mathrm{CO}_{2}$ by the crop can be achieved from added N (McGrath and Lobell 2013); if yield falls, nitrogen ( $\mathrm{N}$ ) requirements would also fall and $N$ translocation affected, due to the grain of stressed plants having less $N$ than control plants (Vignjevic et al. 2015). If stress due to elevated temperature acted early during post-anthesis, cultivars would have reduced capability for synthesising UPP (unextractable polymeric protein) and hence reduce their capacity for tolerance for quality.

In contrast to that reported by Fernández Long et al. (2008), the increases in Tmax, Tmin and Tmean did not result in changes in the thermic amplitude for the period at either site.

Regarding the duration of the period with minimum temperatures equal to or less than $0^{\circ} \mathrm{C}\left(\mathrm{Du} \mathrm{T} \leq 0{ }^{\circ} \mathrm{C}\right)$, no significant differences were observed (Table 1$)$, in coincidence with Alexander et al. (2006) and Easterling et al. $(2000,2002)$.

Extreme temperature

Extreme temperature values have also been subject to change. For example, (i) minimum monthly temperatures (Vmin) have risen significantly at both sites in October $\left(0.019^{\circ} \mathrm{C} /\right.$ year in Azul against $0.055^{\circ} \mathrm{C}$ in $\left.\mathrm{MJ}\right)$ and also in $\mathrm{MJ}$ in November and December $\left(0.046^{\circ} \mathrm{C}\right.$ and $0.041^{\circ} \mathrm{C}$, respectively); (ii) the number of days with temperatures equal to or above $30^{\circ} \mathrm{C}\left(\mathrm{ND} \mathrm{T} \geq 30^{\circ} \mathrm{C}\right)$ rose significantly in $\mathrm{MJ}$ in October $(0.43$ days/decade) and November (0.64 days/decade); and (iii) the degrees accumulated above $30^{\circ} \mathrm{C}\left({ }^{\circ} \mathrm{C} \mathrm{T}>30^{\circ} \mathrm{C}\right)$ also rose in October at $\mathrm{MJ}$ (Table 1). Furthermore, for the variables in (ii) and (iii), the proportion explained for the period 2000-2014 compared to that in the period 1952-2014 at both sites was significant in September (Table 3). These findings coincide with those reported by Plummer et al. (1999) for New Zealand (umbral of $30^{\circ} \mathrm{C}$ ), although not with those of Easterling et al. (2000) for the USA (umbral of $32.2^{\circ} \mathrm{C}$ ). In 
terms of industrial wheat quality, temperatures above $30^{\circ} \mathrm{C}$ break the positive relationship between grain protein content and dough strength, resulting in possible negative effects on quality, with an increase in the gliadin to glutenin ratio.

Mean and extreme rainfall values

Accumulated rainfall for September to December in MJ increased significantly (Table 1), which is consistent with Alexander et al. (2006) at the global level, Barros et al. (1996) and Magrin et al. (2009) in Argentina and Easterling et al. (2000) in the USA. Additionally, all rainfall events equal to or greater than 101.6 $\mathrm{mm}$ recorded in MJ in September and October occurred between 2000 and 2014, with none before that (Table 3). Gelmi and Seoane (2013) found a greater frequency of occurrence of extreme precipitation events over years in the zone including Azul between 1971 to 1999 compared to 1951 to 1970 , implying long term changes appear to be underway at both sites.

Regarding the consequences of these changes, the increase in abundant rainfall events could provoke $\mathrm{N}$ leaching and therefore changes in agronomic practices that could mean that regions of the country hitherto not apt for wheat growing could become so, and vice versa. Future changes could be even more dramatic than the projected changes given in Table 4, since these are likely to be underestimates, given the apparent acceleration of change signalled by the results from 2000 to 2014. Nonetheless, it ought to be remembered that regional precipitation changes can be projected with less certainty than temperature (Zhao et al. 2017).

\section{Differences between sites}

As seen from the results given in Table 4 for the whole period, the variables that changed significantly at both sites did so more pronouncedly in $\mathrm{MJ}$ than in Azul, implying more extreme future conditions at the former site. In contrast, Zhao et al. (2017) found similar impacts at site scale due to temperature increase.

Furthermore, changes in extreme temperature phenomena related to the umbral temperature were only found in MJ, not in Azul. If, besides, we consider that $\mathrm{MJ}$ is, according to its mean and maximum temperatures for each of the months analysed, approximately $5^{\circ} \mathrm{C}$ warmer than Azul, the consequences for yield and quality in MJ could be more severe than in Azul. Naturally future change is related to future gas emission scenarios, as stated by the fourth report of the IPCC, but in general the indications are that climate change will continue and accelerate unless dramatic action is taken to counter it.

The sites were strikingly different in their rates of change for maximum and median temperatures in October across the whole period (Table 1 ). In more recent years, the sites are beginning to differ for the number of days equal to or above $30^{\circ} \mathrm{C}\left(\mathrm{ND} \mathrm{T} \geq 30^{\circ} \mathrm{C}\right)$ and the accumulated degrees above $30^{\circ} \mathrm{C}\left({ }^{\circ} \mathrm{C} \mathrm{T}>30^{\circ} \mathrm{C}\right)$ in September. These changes can increase variability in yield (Hawkins et al., 2013) and quality. In general, more variables have been subject to change, and more intensely, in MJ than in Azul. Nevertheless, adaptation also significantly influenced yield, with adapted crops yielding on average 7-15\% greater than non-adapted (Challinor et al. 2014). The different impact of climate change in these two cities should encourage differential agricultural practices and more studies of climate change impact at the local level. In addition, more extreme measures will probably need to be adopted to ameliorate these changes for yield and quality at these sites, involving, for example, earlier sowing to escape the more extreme months for certain critical stages of plant development.

\section{Consequences of these findings for wheat cultivation}

Our findings suggest climate change is expected in the wheat growing region under study, the magnitude of which will depend upon the particular site involved. A special report of the IPCC (IPCC 2018) shows the consequences for crop production in general, and wheat production in particular, of these sorts of changes. It states that limiting global warming to $1.5^{\circ} \mathrm{C}$, compared with $2^{\circ} \mathrm{C}$, is projected to result in smaller net reductions in yields than would otherwise occur in maize, rice, wheat and potentially other cereal crops, particularly in sub-Saharan Africa, Southeast Asia, and Central and South America, as well as in smaller reductions in the $\mathrm{CO}_{2}$-dependent nutritional quality of rice and wheat. Temperature and precipitation trends have reduced crop production and yields, with the most negative impacts being on wheat and maize, and climate variability has been found to explain more than $60 \%$ of maize, rice, wheat and soybean yield variation in the main global breadbasket areas, with the percentage varying according to crop type and scale. Additionally, the report provides evidence that higher atmospheric $\mathrm{CO}_{2}$ concentration will not compensate for increased temperatures, stating that observations of trends in actual crop yields indicate that reductions as a result of climate change remain more common than crop yield increases, despite increased atmospheric $\mathrm{CO}_{2}$ concentrations. Furthermore, production stimulation at increased atmospheric $\mathrm{CO}_{2}$ concentrations was mostly driven by differences in climate and crop species, whilst yield variability due to elevated $\mathrm{CO}_{2}$ was only about $50-70 \%$ of the variability due to climate. A significant reduction has been projected for global wheat production of $6.0+/-2.9 \%$ for each degree Celsius increase in global mean temperature, and it should be noted that crop production is also negatively affected by the increase in climate extremes, including changes in rainfall extremes, increases in hot nights (Welch et al. 2010, Okada et al. 2011), extremely high daytime temperatures and water stress.

As well as the consequences for yield, the faster growth rates induced by elevated $\mathrm{CO}_{2}$ have been found to coincide with lower protein content in several important C3 cereal grains (Myers et al. 2014), consistent with the reduced grain protein content and hence nutritional quality observed by Taub et al. (2008) and Pleijel and Uddling (2012).

Hence the changes we are projecting in the study have potentially serious consequences for wheat production in Argentina. Assuming the aforementioned $6 \%$ fall in yields per degree Celsius increase in global mean temperature (Asseng et al. 2015, Zhao et al. 2017, IPCC 2018), our mean projections suggest that yields in Azul and Marcos Juaréz could fall by as much as approximately $8 \%$ and $16 \%$, respectively, over the coming one hundred years; the true figures will depend upon many factors, including the coincidence of the temperature changes with the critical yield determining periods in the wheat plant cycle. Although the increase in $\mathrm{CO}_{2}$ could to some extent counteract the negative effects of warming on yield, this would be expected to reach a plateau due to possible feedback mechanisms (Long et al. 2006), whereas the temperatures would be expected to continue to exert deleterious effects in an increasing way over time.

This in turn suggests that considerable countrywide changes in wheat production practices might be needed in the future. The changes in precipitation mentioned by Lovino et al (2011) (see Introduction) have already led to land use changes. It may be the case, as previously mentioned, that some current

Page $12 / 17$ 
wheat growing areas will cease to be apt for this purpose, representing enormous challenges that might only be offset by the conditions in some currently nonwheat growing areas changing to allow wheat to be grown there. This pattern would be expected to occur in wheat growing regions across the globe, unless large-scale remedial actions are implemented.

In this shifting regional and global scenario, what seems certain is that uncertainty lies ahead.

\section{Conclusions}

Two contrasting sites in the current wheat growing region of Argentina (Azul, Province of Buenos Aires and Marcos Juárez, Province of Córdoba) showed changes, broadly consistent with previous studies on climate change (Alexander et al. 2006, Nakicenovic et al. 2007, IPCC 2007c, Trenberth et al. 2007, Fernández Long et al. 2008, Stocker et al. 2013), in both mean and extreme temperature and rainfall values, by analysing climate data from the period of the year in which wheat yield and quality are broadly defined. The possible future scenarios that could result from these changes show greater severity for Marcos Juárez than for Azul, implying greater problems for yield and quality, unless measures can be found that ameliorate the changes; this in spite of the fact that the two sites are only separated by approximately $500 \mathrm{~km}$. As far as we are aware, extreme temperature and rainfall variables had not been previously analysed in this way for these sites.

The first fifteen years of the current century gave greater rates of change than the complete period, implying that future conditions could be even more acute than the simple projections imply, suggesting that new and severe challenges for agronomic production will have to be faced in the future. And, as previously mentioned, warming yield detrimental effects not will be totally countered by $\mathrm{CO}_{2}$ increases, since these are expected to reach a plateau (Long et al. 2006), while temperature increases are expected to continue to rise. This type of study could help to redefine the current "core" regions of different crops in the future.

We consider that the root causes of climate change need to be tackled and where this proves inadequate, alternative remedial action needs to be taken to avert prejudicing crop production in terms of both yield and quality, which would add serious uncertainty to a world already facing enormous challenges in feeding its burgeoning population.

\section{Declarations}

\section{CONFLICTS OF INTEREST}

The authors declare no conflict of interest. The founding sponsors had no role in the design of the study; in the collection, analyses, or interpretation of data; in the writing of the manuscript; or in the decision to publish the results.

\section{ACKNOWLEDGEMENTS}

We are indebted to the National Meteorological Service, who operate the Azul station, for access to the data used in this study.

These results are part of the doctoral thesis of SMLB, who received doctoral studentships from the National Agency for Scientific and Technological Promotion (ANPCyT) and the National Council for Scientific and Technical Research (CONICET).

The study was financed by projects CONICET PIP 11420090100291, CIC-PBA Nº 673/06 and UNCPBA 03/A192 and $03 /$ A215.

-Ethical Approval: Not applicable.

-Consent to Participate: All authors agree with the content of manuscript.

-Consent to Publish: All authors agree with the publication of the content of manuscript.

-Authors' Contributions: S.M.L. Basile, J.A. Tognetti and W.J. Rogers designed the study. S.M.L. Basile performed the analyses. S.M.L. Basile and W.J. Rogers wrote the manuscript. L.M. Gandini supervised and suggested analyses. J.A. Tognetti supervised analyses and criticised the manuscript.

-Funding: The study was financed by projects CONICET PIP 11420090100291, CIC-PBA Nº 673/06 and UNCPBA 03/A192 and $03 /$ A215.

-Competing Interests: Not applicable.

-Availability of data and materials: The climatic data used in this study were provided by Argentinean National Meteorological Service. cim@smn.gov.ar Lic. Ana Teresa Gómez

\section{References}

1. Abbate PE, Lázaro L (2010) Estimación del rendimiento potencial de trigo en Paraguay y sus requerimientos de agua y nutrientes. In: Kholi MM, Cubilla LE, Cabrera G (eds) Del grano al pan. Editorial CAPECO/INBIO, Asunción, Paraguay, pp 11-29

2. Alexander LV, Zhang X, Peterson TC et al (2006) Global observed changes in daily climate extremes of temperature and precipitation. J Geophys Res. https://doi.org/10.1029/2005JD006290

3. Asseng S, Ewert F, Rosenzweig C et al (2013) Uncertainty in simulating wheat yields under climate change. Nat Clim Change. https://doi.org/10.1038/NCLIMATE1916 
4. Asseng S, Ewert F, Martre P et al (2015) Rising temperatures reduce global wheat production. Nat Clim Change. https://doi.org/10.1038/NCLIMATE2470

5. Barros V, Castañeda ME, Doyle M (1996) Variabilidad interanual de la precipitación: Señales del ENSO y del gradiente meridional hemisférico de temperatura. In: 'Impacto de las variaciones climáticas en el desarrollo regional un análisis interdisciplinario'. VII Congreso Latinoamericano e Ibérico de Meteorología, CAM-FLISMET, Argentina, pp 321-322

6. Blain GC (2013) The Mann-Kendall test: the need to consider the interaction between serial correlation and trend. Acta Sci Agron. https://doi.org/10.4025/actasciagron.v35i4.16006

7. Berbery EH, Doyle M, Barros V (2006). Regional precipitation trends. In: Barros V, Clarke R, Silva Días P (eds), Climate change in the La Plata basin. Buenos Aires, CIMA/CONICET-UBA, pp. 61-73

8. Bréon FM, Collins W, Fuglestvedt J et al (2013) Chapter 8: Anthropogenic and Natural Radiative Forcing. In: Climate Change. The Physical Science Basis, IPCC, pp 659-740

9. Cavalcanti IFA, Carril AF, Penalba OC et al (2015) Precipitation extremes over La Plata Basin-Review and new results from observations and climate simulations. J Hydrol. https://doi.org/ 10.1016/j.jhydrol.2015.01.028

10. Challinor AJ, Watson J, Lobell DB et al (2014) A meta-analysis of crop yield under climate change and adaptation. Nat Clim Change. https://doi.org/ 10.1038/nclimate2153

11. Chen X, Tung KK (2014) Varying planetary heat sink led to global-warming slowdown and acceleration. Science. https://doi.org/10.1126/science.1254937

12. De Saedeleer B (2016) Climatic irregular staircases: generalized acceleration of global warming. Sci Rep. https://doi.org/10.1038/srep19881

13. Di Rienzo JA, Casanoves F, Balzarini MG et al (2016) InfoStat versión 2016. Grupo InfoStat, FCA, Universidad Nacional de Córdoba, Argentina. [online]. Available in: http://www.infostat.com.ar

14. Easterling DR (2002) Recent changes in frost days and the frost-free season in the United States. B Am Meteorol Soc. https://doi.org/10.1175/1520-047783.9.1327

15. Easterling DR, Meehl GA, Parmesan C et al (2000) Climate Extremes: Observations, modeling, and impacts. Science. https://doi.org/10.1126/science.289.5487.2068

16. Easterling W, Aggarwal P, Batima P et al (2007) Food, fibre and forest products. In: Parry ML, Canziani OF, Palutikof JP et al (Eds). Climate Change: Impacts, Adaptation and Vulnerability. Contribution of Working Group II to the Fourth Assessment Report of the Intergovernmental Panel on Climate Change, Cambridge University Press, pp. 273-313

17. FAO (Food and Agriculture Organization of the United Nations) (2019) FAOSTAT Producción agrícola [online]. http://www.fao.org/faostat/es/\#data/QC Accessed January 2019

18. Fernández Long ME, Barnatán I, Serio L, Murphy G (2008) Cambios en la disponibilidad térmica para los cultivos de la región pampeana argentina. Rev Fac Agron UBA 28(2,3):111-120. http://ri.agro.uba.ar/files/download/revista/facultadagronomia/2008FernandezLong.pdf

19. Fernández-Long ME, Muller GV, Beltrán-Przekurat A, Scarpati OE (2012) Long-term and recent changes in temperature-based agroclimatic indices in Argentina. Int J Climatol. https://doi.org/10.1002/joc.3541

20. Fraschina JA (2017) Capítulo V: ¿Por qué es importante la calidad del trigo? In: Divito GA, García FO (eds) Manual del cultivo de trigo. International Plant Nutrition Institute. Bs As, Argentina, pp 57-66

21. Foster G, Rahmstorf S (2011) Global temperature evolution 1979-2010. Environ Res Lett. https://doi.org/10.1088/1748-9326/6/4/044022

22. Gelmi M, Seoane R (2013) Variación temporal de índices de precipitaciones extremas en el centro de la Provincia de Buenos Aires. GEOACTA, 38: 47-60

23. Hall AJ, Richards RA (2013) Prognosis for genetic improvement of yield potential and water-limited yield of major grain crops. Field Crops Res. https://doi.org/10.1016/j.fcr.2012.05.014

24. Hawkins E, Osborne TM, Kit Ho C, Challinor AJ (2013) Calibration and bias correction of climate projections for crop modelling: An idealised case study over Europe Agric For Meteorol. https://doi.org/10.1016/j.agrformet.2012.04.007

25. IPCC (2007a) (Intergovernmental Panel on Climate Change). [online]. https://www.ipcc.ch/publications_and_data/ar4/wg1/es/faq-2-1.html Accessed February 2017

26. IPCC 2007b (Intergovernmental Panel on Climate Change). [online]. https://www.ipcc.ch/publications_and_data/ar4/syr/es/mains3-2.html Accessed November 2016

27. IPCC 2007c (Intergovernmental Panel on Climate Change). [online]. http://www.ipcc.ch/publications_and_data/ar4/syr/es/spms3.html Accessed February 2016

28. IPCC (2018) Global Warming of $1.5^{\circ} \mathrm{C}$. An IPCC Special Report on the impacts of global warming of $1.5^{\circ} \mathrm{C}$ above pre-industrial levels and related global greenhouse gas emission pathways, in the context of strengthening the global response to the threat of climate change, sustainable development, and efforts to eradicate poverty. Masson-Delmotte V, Zhai P, Pörtner H-O et al. (eds). In Press

29. Jenner CF (1994) Starch Synthesis in the Kernel of Wheat Under High Temperature Conditions. Aust J Plant Physiol. https://doi.org/10.1071/PP9940791

30. Karl TR, Knight RW (1998). Secular trends of precipitation amount, frequency, and intensity in the United States. Bull Am Meteorol Soc. https://doi.org/10.1175/1520-0477(1998)079<0231:STOPAF>2.0.CO;2

31. Kendall MG (1975) Rank Correlation Methods. Oxford University Press, New York

32. Lobell DB, Schlenker W, Costa-Roberts J (2011) Climate Trends and Global Crop Production Since 1980. Science. https://doi.org/10.1126/science.1204531 


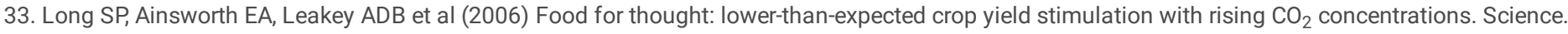
https://doi.org/10.1126/science.1114722

34. Lovino MA, Müller OV, Müller GV et al (2018) Interannual-to-multidecadal hydroclimate variability and its sectoral impacts in northeastern Argentina. Hydrol Earth Syst Sci. https://doi.org/10.5194/hess-22-3155-2018

35. McGrath JM, Lobell DB (2013) Regional disparities in the $\mathrm{CO}_{2}$ fertilization effect and implications for crop yields. Environ Res Lett. https://doi.org/10.1088/1748-9326/8/1/014054

36. Magrin GO, Travasso MI (2002) Chapter 10. An integrated climate change assessment from Argentina. In: Doering O III, Randolph JC, Southworth J, Pfeifer RA (eds) Effects of Climate Change and Variability on Agricultural Production Systems. Kluwer Academic Publishers, Boston, pp 193-219

37. Magrin GO, Travasso MI, Rodriguez GR (2005) Changes in climate and crop production during the 20th century in Argentina. Clim Change. https://doi.org/10.1007/s10584-005-5374-9

38. Magrin GO, Travasso Ml, Rodriguez GR et al (2009) Climate change and wheat production in Argentina. Int J Global Warm. https://doi.org/10.1504/IJGW.2009.027090

39. Mann HB (1945) Non-parametric tests against trend. Econometrica. https://doi.org/10.2307/1907187

40. Martos Núñez VM (2003) Influencia del régimen hídrico sobre componentes de calidad del trigo duro (Triticum durum Desf.) en ambiente mediterráneo. Tesis de Licenciatura en farmacia, Universidad de Granada, Facultad de Ciencias. Granada, España

41. Medhaug I, Stolpe MB, Fischer EM, Knutti R (2017) Reconciling controversies about the 'global warming hiatus'. Nature. https://doi.org/10.1038/nature22315

42. Ministerio de Agricultura de Argentina (2018) Secretaría de Alimentos y Bioeconomía Dirección Nacional de Alimentos y Bebidas. Dirección de Cadenas Alimentarias. CADENA de la HARINA DE TRIGO- RESUMEN.

http://www.alimentosargentinos.gob.ar/HomeAlimentos/Cadenas\%20de\%20Valor\%20de\%20Alimentos\%20y\%20Bebidas/informes/Resumen_Cadena_20 Accessed September 2019

43. Myers SS, Zanobetti A, Kloog I et al (2014) Rising $\mathrm{CO}_{2}$ threatens human nutrition. Nature. https://doi.org/10.1038/nature13179

44. Molfese E (2016) Caracterización de la calidad del trigo pan en el centro sur bonaerense. (1a ed). Argentina: ediciones INTA

45. Moore FC, Lobell DB (2015) The fingerprint of climate trends on European crop yields. Proc. Natl. Acad. Sci. U.S.A. https://doi.org/ 10.1073/pnas.1409606112

46. Nakicenovic N, Alcamo J, Davis G et al (2007) Special Report on Emissions Scenarios, IPCC. Cambridge University Press, Cambridge, UK, 2000. pp. 570

47. Nicholls N (1995) Long term climate monitoring and extreme events. Clim Change. https://doi.org/10.1007/BF01095148

48. Nuñez M, Solman S, Cabré S (2008) Regional climate change experiments over southern South America. Il: climate change scenarios in the late twenty first century. Clim Dyn. https://doi.org/10.1007/s00382-008-0449-8

49. Okada M, lizumi T, Hayashi Y, Yokozawa M (2011) Modeling the multiple effects of temperature and radiation on rice quality. Environ Res Lett. https://doi.org/10.1088/1748-9326/6/3/034031

50. Organización Naciones Unidas (1998) Protocolo de Kioto de la Convención Marco de las Naciones Unidas sobre el Cambio Climático. 25 pp. http://unfccc.int/resource/docs/convkp/kpspan.pdf Accessed December 2019

51. Pleijel H, Uddling J (2012) Yield vs. quality trade-offs for wheat in response to carbon dioxide and ozone. Glob Change Biol. https://doi.org/10.1111/j.1365-2486.2011.2489.x

52. Plummer N, Salinger MJ, Nicholls N et al (1999) Changes in Climate Extremes Over the Australian Region and New Zealand During the Twentieth Century. In: Karl TR, Nicholls N, Ghazi A (eds) Weather and Climate Extremes. Springer, Dordrecht. Holland, pp 183-202

53. Randall PJ, Moss HJ (1990) Some effects of temperature regime during grain filling on wheat quality. Aust J Agric Res. https://doi.org/10.1071/AR9900603

54. Ray DK, Gerber JS, MacDonald GK, West PC (2015) Climate variation explains a third of global crop yield variability. Nat Commun. https://doi.org/10.1038/ncomms6989

55. Re M, Barros VR (2009) Extreme rainfalls in SE South America. Clim Change. https://doi.org/10.1007/s10584-009-9619-x

56. Reynolds M, Foulkes MJ, Slafer GA et al (2009) Raising yield potential in wheat. J Exp Bot. https://doi.org/10.1093/jxb/erp016

57. Rosenzweig C, Elliott J, Deryng D et al (2014) Assessing agricultural risks of climate change in the 21 st century in a global gridded crop model intercomparison. Proc Natl Acad Sci USA. https://doi.org/10.1073/pnas.1222463110

58. Rusticucci M, Barrucand M (2004). Observed trends and changes in temperature extremes over Argentina. J Clim. https://doi.org/10.1175/15200442(2004)017<4099:0TACIT>2.0.C0;2

59. World Bank (2013) Turn Down the Heat: Climate Extremes, Regional Impacts, and the Case for Resilience. A report for the World Bank by the Potsdam Institute for Climate Impact Research and Climate Analytics. Washington, DC: World Bank. License: Creative Commons Attribution-NonCommercialNoDerivatives3.0 Unported license (CC BY-NC-ND 3.0). ISBN (electronic): 978-1-4648-0056-6\$4

60. Schleussner C-F, Lissner TK, Fischer EM et al (2016) Differential climate impacts for policy-relevant limits to global warming: the case of $1.5^{\circ} \mathrm{C}$ and $2{ }^{\circ} \mathrm{C}$. Earth Syst Dyn. https://doi.org/10.5194/esd-7-327-2016

61. Slafer GA, Miralles DJ, Savin R et al (2003) Capítulo 7: Ciclo ontogénico, dinámica del desarrollo y generación del rendimiento y la calidad en trigo. In: Satorre EH, Benech Arnold RL, Slafer GA et al (eds) Producción de Granos. Bases Funcionales para su Manejo. Facultad de Agronomía. Bs. As. Argentina, pp 101-132 
62. StatSoft I (2004) STATISTICA (data analysis software system), version 7. www.statsoft.com. Accessed August 2019

63. Stocker TF, Qin D, Plattner GK et al (2013) Technical Summary. In: Stocker TF, Qin D, Plattner GK et al (eds) Climate Change 2013: The Physical Science Basis. Contribution of Working Group I to the Fifth Assessment Report of the Intergovernmental Panel on Climate Change'. Cambridge University Press, Cambridge

64. Stone PJ, Savin R (1999) Grain quality and its physiological determinants. In: Satorre EH, Slafer GA (eds) Wheat: Ecology and Physiology of Yield Determination. Food Product Press, New York, pp 50-120

65. Taub D, Miller B, Allen H (2008) Effects of elevated CO2 on the protein concentration of food crops: a meta-analysis. Glob Change Biol. https://doi.org/10.1111/j.1365-2486.2007.01511.x

66. Trenberth KE, Jones PD, Ambenje P et al (2007) Observations: surface and atmospheric climate change. In: Solomon S, Qin D, Manning M et al (eds) Climate Change 2007: The Physical Science Basis. Contribution of Working Group I to the Fourth Assessment Report of the Intergovernmental Panel on Climate Change. Cambridge University Press, Cambridge

67. UNFCCC (United Nations Framework Convention on Climate Change) (2016) Report of the Conference of the Parties on its twenty-first session, held in Paris from 30 November to 13 December 2015. Decision 1/CP.21 Adoption of the Paris Agreement. https://unfccc.int/resource/docs/2015/cop21/eng/10a01.pdf

68. Vignjevic M, Wang X, Olesen JE, Wollenweber B (2015) Traits in Spring Wheat Cultivars Associated with Yield Loss Caused by a Heat Stress Episode after Anthesis. J Agron Crop Sci. https://doi.org/10.1111/jac.12085

69. Welch JR, Vincent JR, Auffhammer M et al (2010) Rice yields in tropical/subtropical Asia exhibit large but opposing sensitivities to minimum and maximum temperatures. Proc Natl Acad Sci USA. https://doi.org/10.1073/pnas.1001222107

70. Zhao C, Liu B, Piao S et al (2017) Temperature increase reduces global yields of major crops in four independent estimates. Proc Natl Acad Sci USA. https://doi.org/10.1073/pnas.1701762114

\section{Figures}

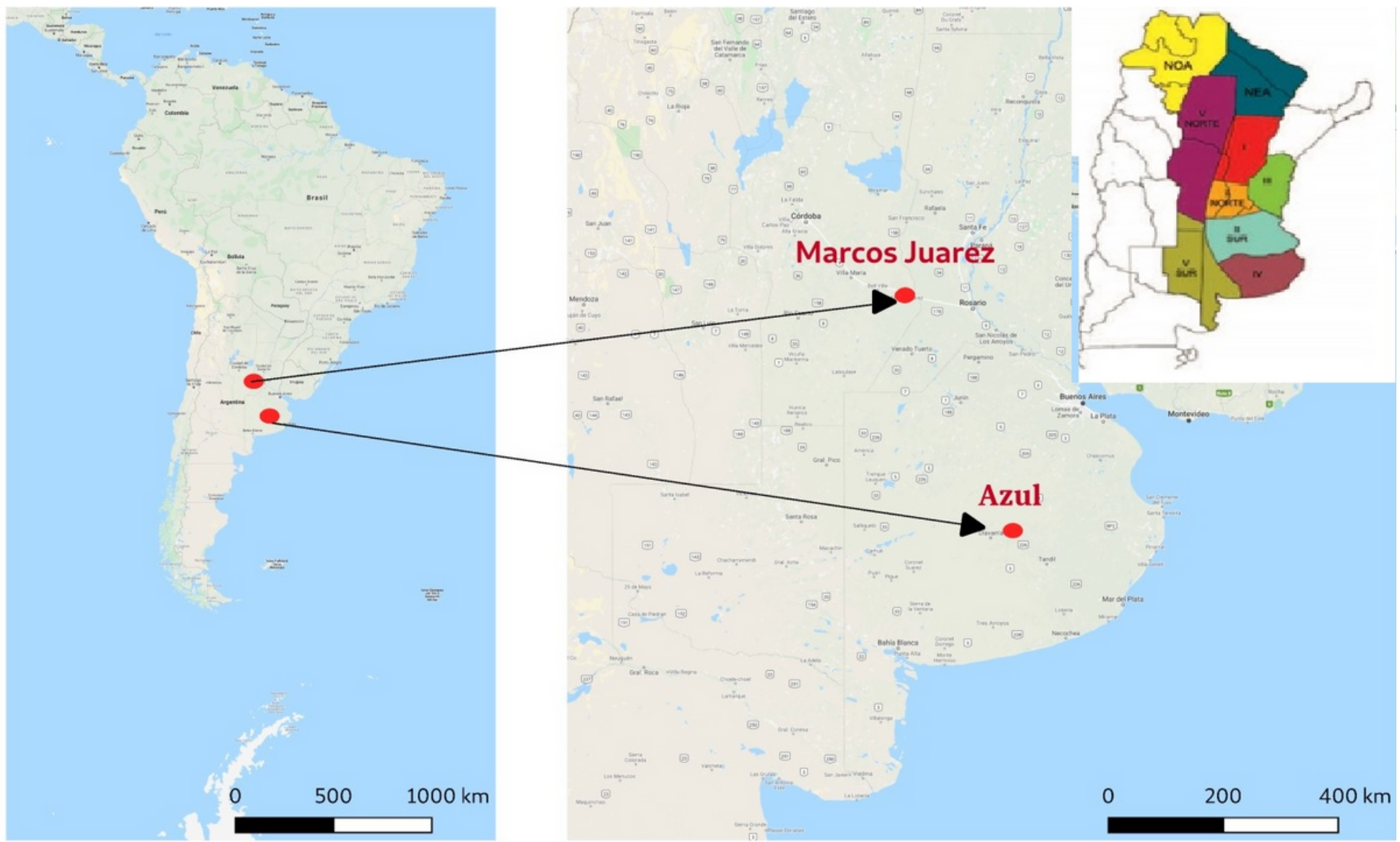

\section{Figure 1}

Location of the sites analysed (Azul, Bs. As. and Marcos Juárez, Córdoba) and map of the wheat growing regions and subregions (upper right) (Molfese, 2016) Note: The designations employed and the presentation of the material on this map do not imply the expression of any opinion whatsoever on the part of Research Square concerning the legal status of any country, territory, city or area or of its authorities, or concerning the delimitation of its frontiers or boundaries. This map has been provided by the authors. 


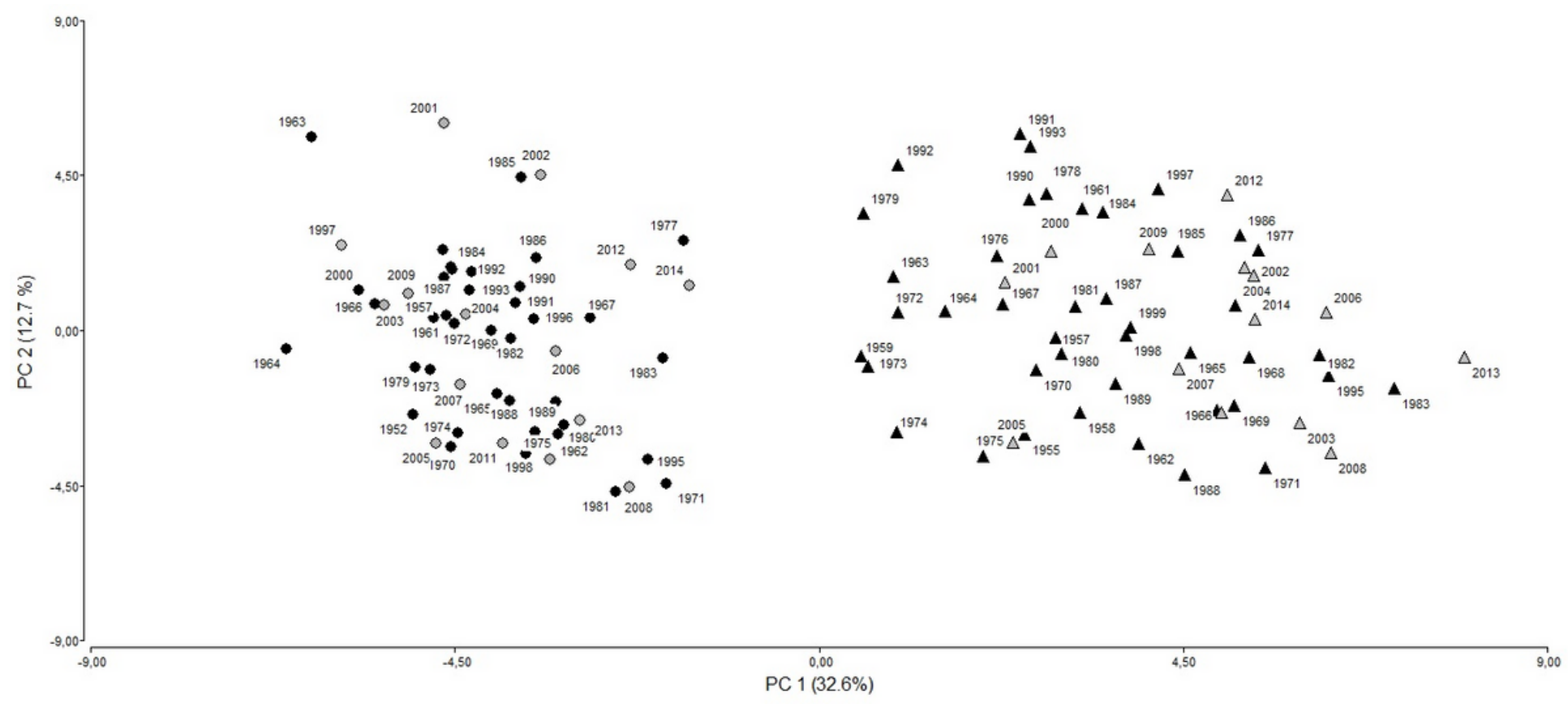

\section{Figure 2}

Principal components (PC) 1 and 2 for both sites during the period September to December 1952-2014. Circles: Azul; triangles: Marcos Juárez; dark symbols: years 1952-1999; light symbols: 2000-2014
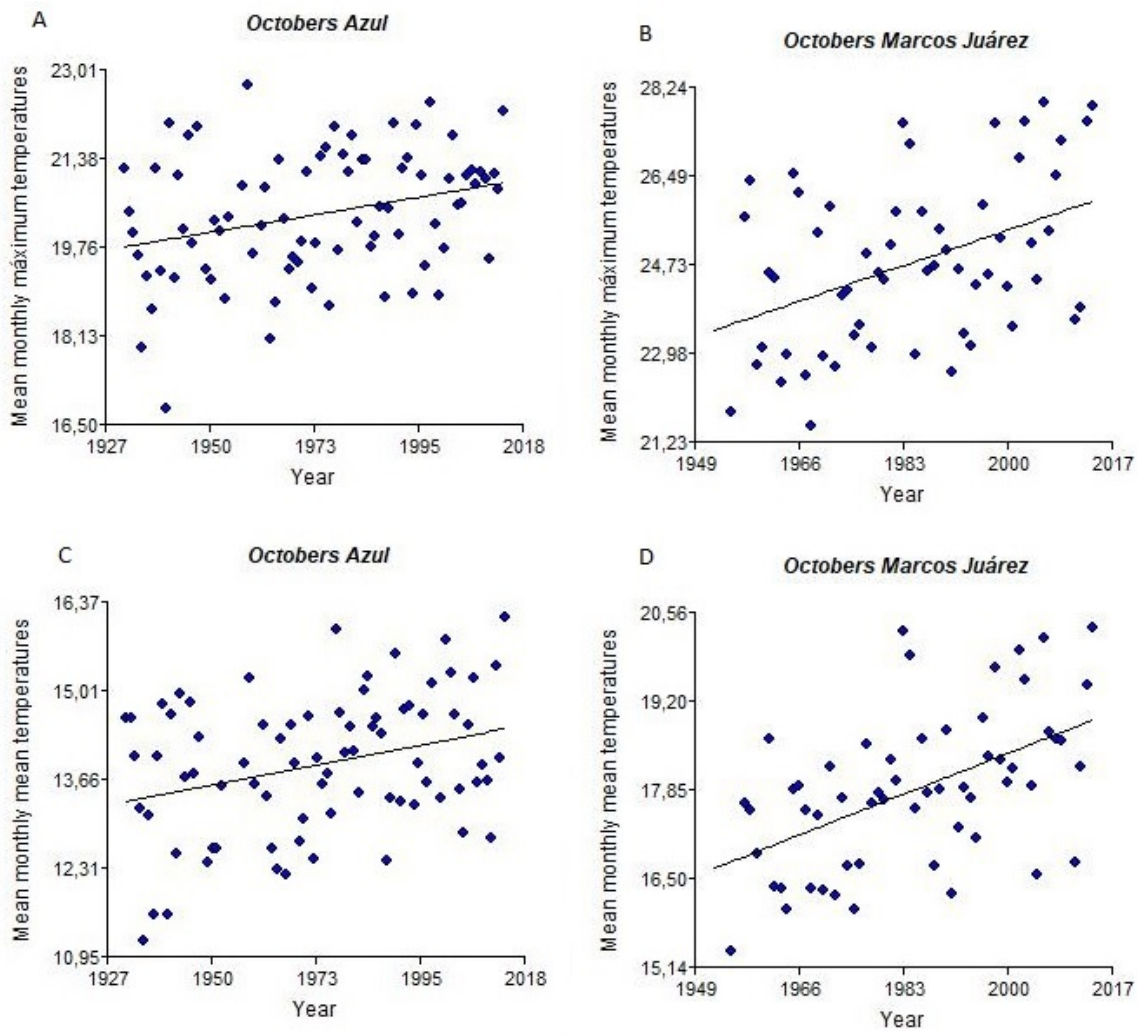

Figure 3

Mean monthly máximum temperatures (Tmax) over years in (A) Azul and (B) Marcos Juárez and mean monthly mean temperatures (Tmean) over years in (C) Azul and (D) Marcos Juárez 